social differentiation amongst the workers. It would be interesting to have his opinion on the formidable social hierarchies still to be found in factory and business organisations where apprenticeship is nonexistent.

\section{University of the Witwatersrand Fire}

We are glad to learn from Dr. W. Cullen, honorary secretary of the committee formed to restore the library of the University of the Witwatersrand, which was destroyed by fire last Christmas Eve, that satis factory response has been made to the appeal for funds and books. So far, about 6000 volumes have been despatched to the University and 4000 have still to go. Mr. J. G. Gubbins, whose name is most intimately associated with the 'Africana Collection', has been in England for several months and, as a result of his efforts, a very remarkable collection of historic material connected with South Africa and the Rhodesias has been brought together, which, if circumstances permit, will be exhibited in London this autumn. Lieut.-Commander Tufnell, nephew of Mr. Gubbins, has generously given $£ 500$ for some exceedingly rare books and prints which Mr. Gubbins has procured for South Africa. The committee has also received from the Imperial Chemical Industries and its subsidiary companies a very useful donation of 1000 technical and scientific books, and from Lord Melchett the residue of his late father's library, which numbers about four hundred volumes. The University authorities have informed the appeal committee that, though funds are limited, they have decided to start building the new fire-proof library, but will only complete it as the necessary money becomes available.

\section{The Children's Museum in Brooklyn}

THrs interesting venture made unprecedented growth and expansion in attendance and activities in 1931. The city's effort to find emergency employ. ment resulted in a welcome temporary addition to the workers, who at one time numbered so many as a hundred. The Museum has three main aims : to give children joy and satisfaction through wholesome activity ; to make their education fun ; and to give them a consciousness of ability to succeed (Museums of The Brooklyn Institute of Arts and SciencesReport for the Year 1931). It follows these aims through six divisions of activity-lectures, docentry, loans, boy scouts, mineralogy and the libraryand much ingenuity is shown in the methods of laying hold of the childish interests. For example, there is the jig-saw puzzle section, where the puzzles, made in the Museum and related to the exhibits, now number 1000 , and were used by 111,727 children. But this ploy demanded a preliminary, and we are told that one coloured woman, Estelle Hall, presided at the washing of 143,577 pairs of [coloured] hands in preparation for assembling puzzles and handling books. The loan division now owns 3812 exhibit cases, many boxed by emergency workers, and during the year these loans made 2,350,260 contacts in the 688 schools which borrowed them.

\section{Extension of the Piccadilly Railway}

The Piccadilly railway originally ran from Hammersmith to Finsbury Park, a distance of $8 \frac{1}{2}$ miles through the centre of London. It is now being extended and on completion next year will be 25 miles long and will run from west to north across Greater London. The section from Hammersmith to Acton Town has been running for some weeks. The section from Finsbury Park to Arnos Grove, South. gate, was opened on Sept. 19. Each station with the exception of Arnos Grove is fitted with three escalators. The running of the trains will be notified to passengers by 'describers' showing the destination and the stations at which stops will be made. Although there are twelve different stations, only two connecting wires are required for operating the describers. A $2 \frac{3}{4}$ minutes service will be run to and from Wood Green and a $5 \frac{1}{2}$ minutes service to Arnos Grove. This requires 347 trains each way between Wood Green and Hammersmith and made it neces. sary to provide 275 new cars. The motor cars are equipped with two 240 horsepower motors and the average speed including stops is $\mathbf{2 5}$ miles per hour. The electrical energy is obtained on the three phase system from the North Metropolitan Electric Power Supply Company. There are three substations each of which contains three 1500 kilowatt mercury arc rectifiers for converting the power to the direct current system required by the motors. These converters have been made by the British Thomson-Houston Company at Rugby and embody improvements. The line is equipped with automatic signals of the colour light type. These are controlled by track circuits and provided with train stops.

\section{Announcements}

IT is announced that Dr. G. C. Anderson, deputy medical secretary of the British Medical Association since 1919, has been appointed medical secretary of the Association in succession to Dr. Alfred Cox, who has retired.

THE following awards were made at the Council meeting of the Royal Aeronautical Society held on Sept. 20: Silver Medal, to Senhor Juan de la Cierva, for his work in connexion with the development of the autogiro; Simms Gold Medal, to Mr. P. Salmon, for his paper and work on catapults ; Wakefield Gold Medal, to Mr. L. G. Frise, for his invention of the Frise aileron; R.38 Memorial Prize, to Mr. D. H. Williams and Mr. A. R. Collar for their joint paper on "The Motion of an Airship under Certain Conditions"; Pilcher Memorial Prize, to Mr. Dowsett, for his paper on "The Design of Aeroplane Controls and Control Systems".

APPLICATIONS are invited for the following appointments, on or before the dates mentioned :-An assistant investigator in the Safety in Mines Research Board tenable at Sheffield-The Under-Secretary for Mines, Establishment Branch, Mines Department, Cromwell House, Dean Stanley Street, Millbank, London, S.W.1 (Oct. 22). A biochemist at the Queen's Hospital, Birmingham-The House Governor (Oct. 31).

No. 3284, VoL. 130] 